\title{
Mentha piperita protects against Cadmium induced oxidative renal damage by restoring antioxidant enzyme activities and suppressing inflammation in rats
}

\author{
S.Thangapandiyan, NC Sumedha and S.Miltonprabu* \\ Faculty of Science, Department of Zoology, Annamalai University, Annamalai nagar, Chidambaram, Tamil Nadu, India \\ *Corresponding author E-mail: smprabu73@gmail.com
}

\begin{abstract}
Background:

The aim of this study was to investigate the possible protective role of the Mentha piperita leaf extract (MPE) on cadmium $(\mathrm{Cd})$-induced nephrotoxicity using biochemical and histopathological approaches.

Methods:

The control group received the vehicles only. The $\mathrm{Cd}$ treated group received $\mathrm{Cdcl}_{2}(5 \mathrm{mg} / \mathrm{kg})$ orally in isotonic saline for 4weeks. Cd + MPE treated group received the MPE at a dose of (100mg/kg in 5\% tween 80) along with Cd. MPE alone treated group received the MPE alone orally at a dose of $100 \mathrm{mg} / \mathrm{kg}$ in $5 \%$ tween 80 for 4 weeks.

\section{Results:}

In experimental rats oral administration of $\mathrm{CdCl}_{2}(5 \mathrm{mg} / \mathrm{kg})$ for 4 weeks significantly induced renal damage which was evident from the increased levels of serum urea, uric acid and creatinine with a significant $(\mathrm{p}<0.05)$ decrease in creatinine clearance. Cd also significantly $(\mathrm{p}<0.05)$ decreased the levels of urea, uric acid and creatinine in urine. Cdinduced oxidative stress in kidney tissue was indicated by the increased levels of renal lipid peroxidation markers (thiobarbituric acid reactive substances and lipid hydro peroxides) and protein carbonyl content with a significant $(\mathrm{p}<0.05)$ decrease in non- enzymatic (total sulfhydryl group, reduced glutathione, vitamin $\mathrm{C}$ and $\mathrm{E}$ ) and enzymatic antioxidants (superoxide dismutase (SOD), catalase (CAT), glutathione peroxidase (GPx), glutathione S-transferase $(\mathrm{GST})$, glutathione reductase $(\mathrm{GR})$. Moreover the kidneys of Cd-treated rats also exhibit significantly $(\mathrm{p}<0.05)$ increased levels of tumor necrosis factor (TNF- $\alpha$ ) and nitric oxide (NO). The histopathology of Cd treated rats showed tubular necrosis, degeneration, dilation, desquamation, thickening of basement membrane and luminal cast formation. MPE $(100 \mathrm{mg} / \mathrm{kg} /$ day) treatment markedly attenuated the Cd-induced biochemical alterations in serum, urine and renal tissue, and brings the TNF- $\alpha$ and NO in to normal levels. MPE also ameliorated the Cd-induced pathological changes when compared with $\mathrm{Cd}$-alone-treated group.

Conclusions:

These results indicate that the natural dietary antioxidant MPE might have significant protective effect against Cdinduced oxidative stress mediated in rats. Due to its antioxidant and anti-inflammatory effects, it will provide an accessible and cheap traditional medicine source for treatment of $\mathrm{Cd}$ mediated environmental and occupational ailments.
\end{abstract}

Keywords: Mentha Piperita, Cadmium, Kidney, Renal Markers, Inflammatory Markers, Rat.

\section{Introduction}

Cadmium is a ubiquitous environmental toxicant that affects biological systems in various ways. The molecular mechanisms of its toxicity are not yet well defined. Humans are exposed to cadmium from the sources of tobacco smoke, food, industrial, occupational and environmental pollution. Cadmium exposure has been shown to have adverse effects on a variety of tissues and is linked with various chronic diseases. It has long been recognized as one of the most toxic environmental and occupational heavy metal pollutant [1]. Cd stimulates the formation of reactive oxygen species, including oxygen free anion radical [2], hydrogen peroxide [3] and probably hydroxyl radical [4]. As a consequence, enhanced lipid peroxidation, DNA damage, altered calcium and sulfhydryl homeostasis, as well as marked disturbances of antioxidant defense system (ADS) occur [5]. Cd-related diseases including cardiovascular disease, hypertension, osteoporosis, nephrotoxicity, hepatotoxicity, diabetes, and cancers of many organs [6]. Mechanism of cadmium toxicity may be multifactorial. It has been suggested that cadmium acts as a catalyst in the oxidative reactions of biological 
macromolecules, and therefore, the toxicities associated with the metal might be due to the oxidative tissue damage. Cadmium being a redox-inactive metal cannot undergo redox cycling but deplete the cells with their major antioxidants, particularly thiol-containing antioxidants and enzymes [7]. Kidneys are one of the most critical organs for the toxicity of $\mathrm{Cd}$; the oxidative effect of $\mathrm{Cd}$ is indirect and based mainly on the depletion of sulfhydryl (SH)-group-containing compounds [8]. Cd itself is unable to generate free radicals directly. Several lines of evidences indicate that oxidative stress and reactive oxygen species formed in the presence of $\mathrm{Cd}$ could be responsible for its toxic effects in various organs [9].

The nephrotoxic action of $\mathrm{Cd}$ may be mediated by $\mathrm{Cd}$-metallothionein (MT) complex released from the damaged kidney cells filtered through the glomerulus into the urinary space, where it is endocytosed by the proximal tubular cells and degraded by the lysosomes, resulting in the release of $\mathrm{Cd}$ [10]. The released $\mathrm{Cd}$ may then stimulate the production of MT in proximal tubular cells, directly damage the integrity of microvilli and intracellular vesicles [11], indirectly inhibit the transporter activity through changes in the membrane fluidity due to oxidative stress, increase the lipid peroxidation by binding with membrane phospholipids [12] and target various intracellular proteins and membrane transporters at the cytoplasmic side by binding to their reactive $\mathrm{SH}$ groups [13]. In order to combat against Cd-induced oxidative renal damage, antioxidant phytochemicals may be the suitable antidotes because of their high antioxidant nature and low toxicity. The flavonoids are a family of phenolic compounds that possess a remarkable spectrum of biochemical and pharmacological activities like antibacterial, antiviral, antiinflammatory, antiallergic, antithrombotic, antimutagenic, antineoplastic, as well as neuroprotective properties [14]. Mentha piperita (Lamiaceae), the peppermint (mint) plant is an aromatic perennial herb cultivated in most part of the world, have traditionally been used in folk medicine. Mentha commonly known as peppermint has shown antioxidant and antiperoxidative properties due to the presence of eugenol, caffeic acid, rosmarinic acid and $\alpha$-tocopherol [15-17]. The essential oil is widely used as flavoring and/or additive in foods, toothpaste, and other hygienic products, and in pharmaceutical formulations [18]. A large volume of literature is available on the medicinal properties of essential oils present in Mentha spp. [19, 20]. Several studies have shown that M. piperita has antibacterial, antioxidant, antitumor and antiallergenic potential [21, 22]. The possible nephroprotective action of M.Piperita leaf extract against $\mathrm{Cd}$ induced nephrotoxicity has not been explored so far. Therefore, in this study, we intended to evaluate the nephroprotective consequence of M.Piperita leaf extract against $\mathrm{Cd}$-induced sub-chronic oxidative kidney damage in rats.

\section{Materials and methods}

\subsection{Chemicals}

Cadmium chloride, 2-thiobarbituric acid (TBA), butylated hydroxytoluene (BHT), reduced glutathione (GSH), 2,2dipyridyl, xylenol orange, 2,4-dinitrophenylhydrazine (DNPH), cglutamyl-p-nitroanilide, 5,5-dithiobis-2-nitrobenzoic acid were obtained from Sigma Chemical Co. (St. Louis, MO, USA). The rest of the chemicals utilized were obtained from a local firm (India) and were of analytical grade.

\subsection{Plant material and extract preparation}

Fresh M.Piperita leaves were collected during the month of February 2012, from local market Chidambaram. The leaves were identified and authenticated by a herbalist, Department of Botany, Annamalai University. The voucher specimen (Herbarium no: 113/2008) was stored in the Department of Botany.

\subsubsection{Preparation of ethanolic extract of the leaves of M.Piperita (MPE)}

The fresh leaves of M.Piperita were washed and shade dried for one week. The air dried leaves were milled into fine powder in a commercial blender. The powder $(500 \mathrm{~g})$ was Soxhlet extracted with $95 \%$ ethanol $\left(1: 3\right.$, w/v) at $37^{\circ} \mathrm{C}$ for two days. The resultant extract was concentrated to dryness under reduced pressure and was freeze dried. The total yield was $8.17 \mathrm{~g}(1.63 \%$, w/w) of light greenish brown extract. The ethanolic leaf extract of M.Piperita (MPE) was reconstituted to a final concentration of $5 \%(\mathrm{w} / \mathrm{v})$ using aqueous solution of gum acacia $(5 \%)$ for further treatments.

\subsection{Dosage fixation}

The animals were administered MPE orally (in 5\% tween 80 ) up to 28 days (25, 50 and $100 \mathrm{mg} / \mathrm{kg}$ body weight), and lipid peroxidation (LPO) and glutathione (GSH) content was measured in the kidney of rats challenged with Cd. The optimum dose selection of MPE was done on the basis of maximum prevention of GSH depletion and minimum LPO content. From these doses, a dose of $100 \mathrm{mg} / \mathrm{kg}$ body weight of MPE was found to be most suitable against Cd induced renal toxicity. Further detailed investigations were done with this effective $(100 \mathrm{mg} / \mathrm{kg})$ dose. 


\subsection{Animals}

Male albino Wistar rats, body weight of 160-180 g bred in Central Animal House, Rajah Muthiah Medical College, Annamalai University, were used in this study. Throughout the study, the animals were housed six animals per each polypropylene cage and were maintained in accordance with the guidelines of the National Institute of Nutrition, Indian Council of Medical Research, Hyderabad, India, and approved by the Institutional Animal Ethical Committee (Reg No. 160/1999/CPCSEA, Proposal number: 952/2012), Annamalai University. The rats were allowed standard rat pellet diet (Lipton India Ltd., Mumbai, India) and water ad libitum for the duration of the experiment.

\subsection{Experimental design}

The rats were randomly divided into four groups of six rats in each group Group 1: Control rats intragastrically administered with vehicles alone.

Group 2: Rats intragastrically administered with MPE (100 mg/kg/day) for 28 days using intragastric tube.

Group 3: Rats orally received Cd as cadmium chloride ( $5 \mathrm{mg} / \mathrm{kg} / \mathrm{day})$ [23] in saline for 28 days.

Group 4:Rats received MPE (100 mg/kg/day) followed by oral administration of Cd As cadmium chloride (5 $\mathrm{mg} / \mathrm{kg}$ / day) for 28 days.

Food and water intake was recorded and rats were weighed every week. Forty-eight hours after the administration of the last dose, the animals were anesthetized with an intramuscular injection of ketamine hydrochloride $(24 \mathrm{mg} / \mathrm{kg})$ and sacrificed by decapitation. Blood was collected in tubes for the separation of serum. The kidney tissue was dissected out, weighed and washed using chilled saline solution. Tissue was minced and homogenized (10\%, w/v) in phosphate buffer (pH 7.4) and centrifuged (3000xg for $10 \mathrm{~min}$ ). The resulting clear supernatant was used for various enzymatic and nonenzymatic biochemical assays. Six rats from each group were sacrificed and used for analyzing serum and tissue biochemical assays.

\subsection{Biochemical assays}

\subsubsection{Determination of total phenolic and total flavonoid contents}

Total phenolic content in the extract was determined by Folin-Ciocalteu method [24], and it was expressed as gallic acid equivalents (GAE) (mg/g). Total flavonoids content in the extract was measured as described previously [25] and it was calculated as rutin equivalents $(\mathrm{mg} / \mathrm{g})$.

\subsubsection{Estimation of urea, uric acid, creatinine and creatinine clearance}

The levels of urea, uric acid and creatinine in serum and urine were estimated spectrophotometrically using commercial diagnostic kits (Sigma Diagnostics (I) Pvt. Ltd., Baroda, India). Creatinine clearance as an index of glomerular filtration rate was calculated from serum creatinine and a $24 \mathrm{~h}$ urine sample creatinine levels.

\subsubsection{Determination of lipid peroxidation and oxidative stress markers}

Lipid peroxidation in the kidney was estimated spectrophotometrically by measuring thiobarbituric acid reactive substances and lipid hydroperoxides by the method of [26] and [27] respectively. Protein carbonyl content was determined by the method of [28]. The levels of conjugated dienes were assessed by the method of [29].

\subsubsection{Determination of non-enzymatic and enzymatic antioxidants}

Reduced glutathione was determined by the method of [30]. Oxidized glutathione was estimated by the method of [31]. Total sulfhydryl groups were measured by the method of [32]. Vitamin C concentration was measured as previously reported by [33]. Vitamin E (a-tocopherol) was estimated by the method of [34]. Superoxide dismutase activity was determined by the method of [35]. The activity of catalase was determined by the method of [36]. Glutathione peroxidase activity was estimated by the method of [37]. Glutathione S-transferase activity was determined by the method of [38]. Glutathione reductase was assayed by the method of [39]. The estimation of glucose-6-phosphate dehydrogenase was carried out by the method of [40].

\subsubsection{Estimation of membrane-bound ATPase}

The sediment after centrifugation was re suspended in ice cold Tris- $\mathrm{HCl}$ buffer $(0.1 \mathrm{M}) \mathrm{p}^{\mathrm{H}} 7.4$. This was used for the estimations of membrane-bound enzymes and protein content. The membrane bound enzymes such as $\mathrm{Na}^{+} / \mathrm{K}^{+}$-ATPase, $\mathrm{Ca}^{2+}$-ATPase and $\mathrm{Mg}^{2+}$-ATPase activity were assayed by estimating the amount of phosphorous liberated from the incubation mixture containing tissue homogenate, ATP and the respective chloride salt of the electrolytes [41, 42, 43]. Total protein content was estimated by the method described by [44]. 


\subsubsection{Assay of renal nitric oxide (NO) and TNF-a}

The NO was indirectly measured by determining the nitrite level using colorimetric assay kit as indicated by the manufacturer (Cayman Chemical Company, USA) based on the Griess reaction [45]. Also, the level of tumor necrosis factor-a (TNF-a) in renal homogenates was determined by enzyme linked immunosorbent assay using mouse TNF-a immunoassay kit according to the recommendations of the manufacturer (R\&D Systems, USA).

\subsection{Histopathological studies}

For qualitative analysis of Kidney histology, the tissue samples were fixed for $48 \mathrm{~h}$ in $10 \%$ formalin-saline and dehydrated by passing successfully in different mixture of ethyl alcohol, water, cleaned in xylene and embedded in paraffin. Sections of the tissues $(5-6 \mu \mathrm{m}$ thick) were prepared by using a rotary microtone and stained with hematoxylin and eosin dye, which was mounted in a neutral deparaffined xylene medium for microscopical observations. Six rats from each group were sacrificed for analyzing the kidney histological examinations

\subsection{Statistical analysis}

Data were analyzed by one way analysis of variance (ANOVA) followed by Duncan's multiple range test (DMRT) using a commercially available statistics software package (SPSS_for Windows, V. 13.0, Chicago, USA). Results were presented as mean \pm SD. p values $<0.05$ were regarded as statistically significant.

\section{Results}

\subsection{Total phenolic and total flavonoid contents}

Total phenolic content estimated as $257.2 \pm 10.5 \mathrm{mg}$ gallic acid equivalent/g dry weight of the extract. Total flavonoid content estimated as $212.7 \pm 9.7 \mathrm{mg}$ rutin equivalents/g dry weight of the extract.

\subsection{Body weight gain, food intake, water intake and organ body weight ratio}

Table 1 shows the effects of Cd, MPE on body weight gain, food and water intake and organ-body weight ratio (\%) in control and experimental rats. In Cd treated rats the water, pellet diet consumption significantly $(\mathrm{P}<0.05)$ decreased with decreased in body weight. A significant $(\mathrm{P}<0.05)$ increase in kidney body weight ratio was recorded in $\mathrm{Cd}$ intoxicated rats when compared with control rats. Administration of MPE significantly $(\mathrm{P}<0.05)$ recovered Cd induced changes in food, water intake, body weight gain and kidney body weight ratio when compared with $\mathrm{Cd}$ alone treated rats. Administration of MPE alone did not show any significant alterations in those parameters and did not differ significantly from the normal control group.

Table 1: Body weight, absolute and renal kidney weight, food and water intake in control and experimental rats.

\begin{tabular}{|c|c|c|c|c|c|c|c|}
\hline \multirow[t]{2}{*}{ Groups } & \multicolumn{3}{|l|}{ Body weight } & \multirow{2}{*}{$\begin{array}{l}\text { Absolute kidney } \\
\text { weight }(\mathrm{g})\end{array}$} & \multirow{2}{*}{$\begin{array}{l}\text { Relative } \\
\text { kidney } \\
\text { weight } \\
\text { (g/100 g } \\
\text { bw) }\end{array}$} & \multirow{2}{*}{$\begin{array}{l}\text { Food } \\
\text { intake(g/ } \\
100 \mathrm{~g} \mathrm{bw/} \\
\text { day }\end{array}$} & \multirow{2}{*}{$\begin{array}{l}\text { Water intake } \\
\text { (mL/rat/day) }\end{array}$} \\
\hline & Initial (g ) & Final(g) & \%Change & & & & \\
\hline Control & $160.00 \pm 1.89$ & $174.00 \pm 3.52$ & $10.68 \pm 0.49^{a}$ & $1.52 \pm 0.02^{\mathrm{a}}$ & $0.57 \pm 0.05^{\mathrm{a}}$ & $12.15 \pm 1.17$ & $20.16 \pm 2.07$ \\
\hline MPE & $158.00 \pm 2.16$ & $174.00 \pm 2.74$ & $11.23 \pm 0.50^{\mathrm{a}}$ & $1.90 \pm 0.04^{\mathrm{a}}$ & $0.58 \pm 0.06^{\mathrm{a}}$ & $12.85 \pm 1.10$ & $20.76 \pm 2.10$ \\
\hline $\mathrm{Cd}$ & $156.00 \pm 2.32$ & $146.00 \pm 2.54$ & $6.53 \pm 0.40^{b}$ & $1.32 \pm 0.01^{\mathrm{b}}$ & $0.41 \pm 0.05^{\mathrm{b}}$ & $7.17 \pm 0.85$ & $14.34 \pm 1.56$ \\
\hline $\mathrm{Cd}+\mathrm{MPE}$ & $158.00 \pm 1.38$ & $171.00 \pm 2.53$ & $9.57 \pm 0.59^{c}$ & $1.53 \pm 0.03^{\mathrm{c}}$ & $0.44 \pm 0.04^{\mathrm{c}}$ & $10.54 \pm 1.18$ & $16.58 \pm 1.70$ \\
\hline
\end{tabular}

Values are given as mean \pm SD from six rats in each group. Values not sharing a common superscript letter (a-c) differ significantly at $\mathrm{p}<0.05(\mathrm{DMRT})$

\subsection{Serum and urine markers}

A significant $(p<0.05)$ increase in the level of urea, uric acid and creatinine in serum and with significant $(p<0.05)$ decrease in the level of creatinine clearance was observed in Cd-treated rats when compared with normal rats. Administration of MPE $(100 \mathrm{mg} / \mathrm{kg}$ day) along with Cd significantly $(\mathrm{p}<0.05)$ restored the levels of urea, uric acid, creatinine and creatinine clearance to near normal levels when compared with Cd-alone- treated rats (Fig. 1). The levels of urea, uric acid and creatinine in the urine were significantly $(\mathrm{p}<0.05)$ decreased in Cd-intoxicated rats when 
compared with normal control rats. Simultaneous administration of Cd along with MPE significantly $(\mathrm{p}<0.05)$ restored the levels of urea, uric acid and creatinine in urine when compared with Cd-alone-treated rats (Fig. 2).

\section{A}

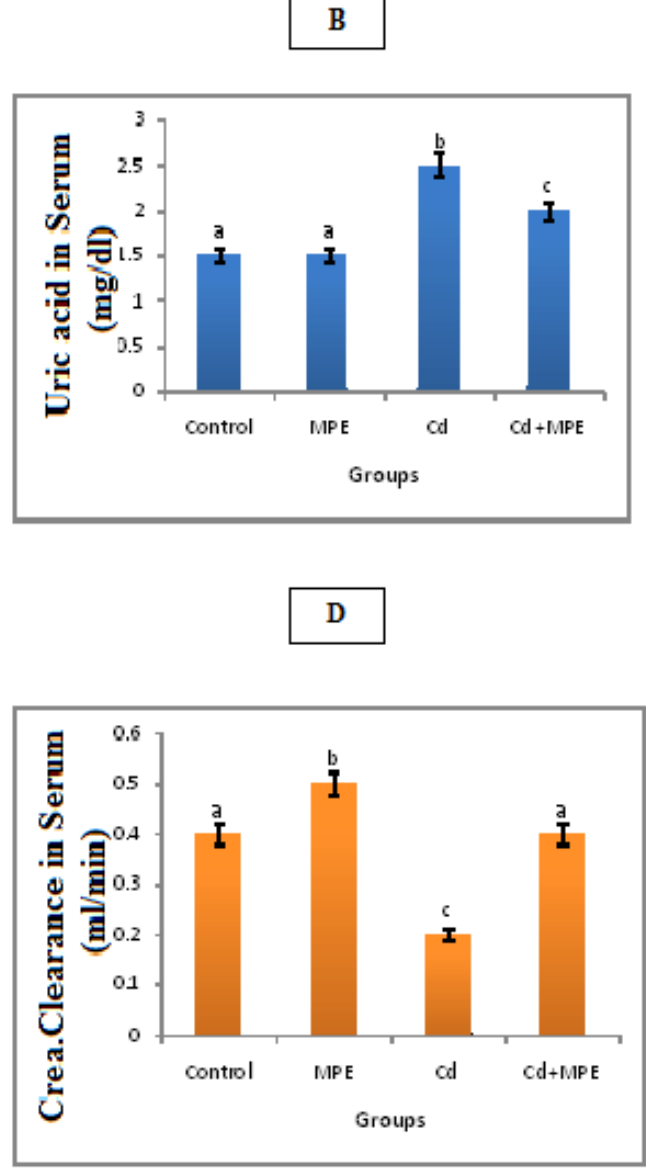

Fig. 1: Effect of MPE on Cd-induced changes in renal functional markers: (A) urea (B) uric acid (C) creatinine (D) creatinine clearance in serum of male albino Wistar rats. Values are mean \pm S.D. for six rats in each group. Bars not sharing a common superscript letter (a-c) differ significantly at $p$ $<0.05$ (DMRT).

\subsection{Oxidative stress markers}

Changes in the levels of renal lipid peroxidation, lipid hydroperoxides (LOOH) and protein carbonyls (PC) in control and experimental rats are shown in Table 2. The levels of lipid peroxidation products namely TBARS, LOOH and PC significantly $(\mathrm{p}<0.05)$ increased in $\mathrm{Cd}$ treated rats when compared with the control groups. Administration of MPE along with Cd significantly $(\mathrm{p}<0.05)$ decreased the levels of TBARS, LOOH and PC in the kidney tissue of rats when compared to $\mathrm{Cd}$ treated rats. Administration of MPE alone significantly $(\mathrm{p}<0.05)$ reduced the levels of TBARS, LOOH and $\mathrm{PC}$ when compared with the control group.

Table 2. Effect of MPE on cadmium induced alterations in the levels of lipid peroxidation, lipid hydro peroxides and protein carbonyl content in kidney of control and experimental rats.

\begin{tabular}{|c|c|c|c|c|}
\hline Groups & Control & MPE & $\mathrm{Cd}$ & $\mathrm{Cd}+\mathrm{MPE}$ \\
\hline TBARS (mg/g tissue) & $2.31 \pm 0.14^{\mathrm{a}}$ & $2.19 \pm 0.13^{\mathrm{a}}$ & $4.09 \pm 0.35^{b}$ & $2.82 \pm 0.17^{\mathrm{c}}$ \\
\hline $\mathrm{LOOH}(\mathrm{mmol} / \mathrm{g}$ tissue $)$ & $0.54 \pm 0.04^{\mathrm{a}}$ & $0.55 \pm 0.05^{\mathrm{a}}$ & $0.90 \pm 0.08^{b}$ & $0.72 \pm 0.06^{\mathrm{c}}$ \\
\hline $\mathrm{PC}$ (nmol/mg protein) & $1.70 \pm 0.12^{\mathrm{a}}$ & $1.72 \pm 0.13^{\mathrm{a}}$ & $4.50 \pm 0.34^{b}$ & $2.39 \pm 0.18^{\mathrm{c}}$ \\
\hline
\end{tabular}

Values are mean \pm SD for 6 rats in each group.

${ }^{a}$, $\&$ c Values not sharing a common superscript letter (a,b \&c) differ significantly at $p<0.05$ (DMRT). 


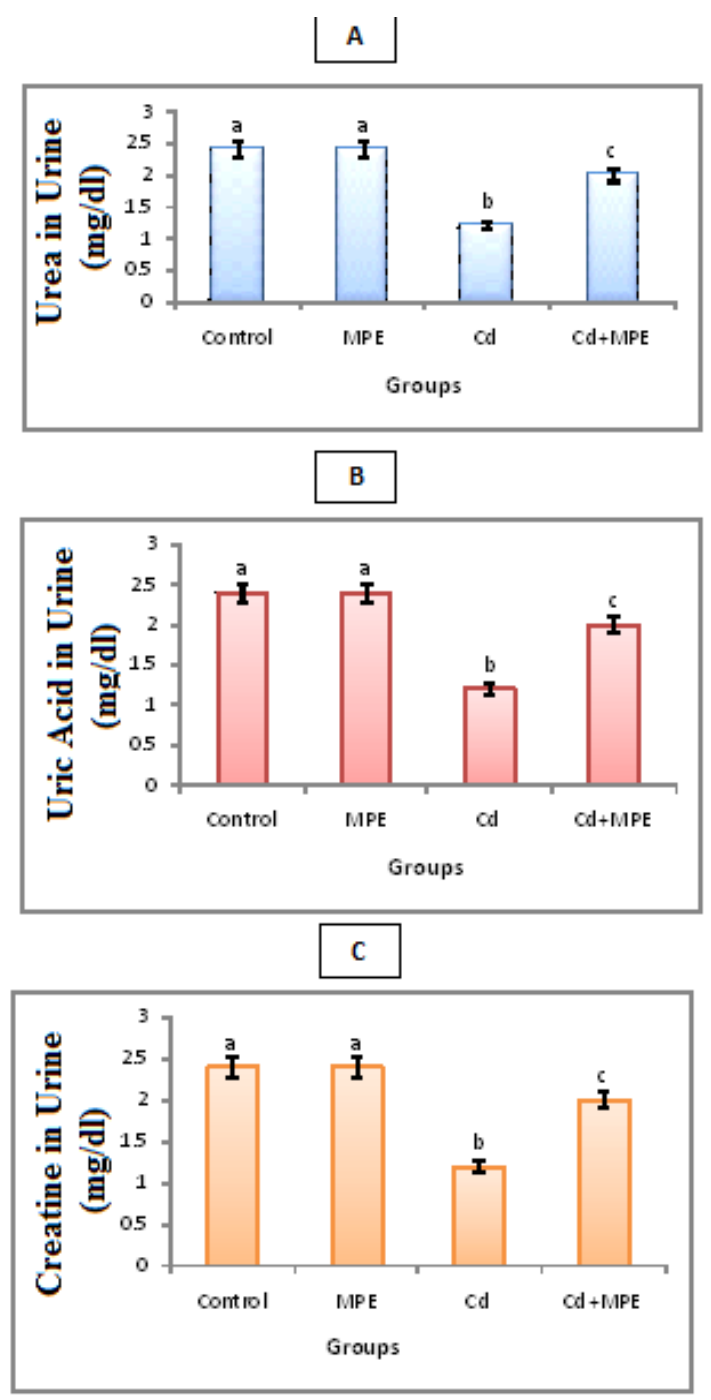

Fig. 2: Effect of MPE on Cd-induced changes in renal functional markers: (A) urea (B) uric acid (C) creatinine in urine of male albino Wistar rats. Values are mean \pm S.D. for six rats in each group. Bars not sharing a common superscript letter (a-c) differ significantly at $p<0.05$ (DMRT).

\subsection{Enzymatic antioxidants status}

Changes in the levels of renal enzymatic antioxidants in control and experimental rats were shown in Table 3. A significant $(\mathrm{p}<0.05)$ decrease in the activities of enzymatic antioxidants (SOD, CAT, GPx, GST) were observed in Cd-treated rats. Administration of MPE $(100 \mathrm{mg} / \mathrm{kg}$ day) along with $\mathrm{Cd}$ treated rats exhibited a significant $(\mathrm{p}<0.05)$ increase in the levels of enzymatic antioxidants when compared with Cd treated kidney of rats.

Table 3: Effect of MPE and cadmium on the activities of enzymatic antioxidants in kidney of control and experimental rats.

\begin{tabular}{lllll}
\hline Groups & Control & MPE & Cd & Cd+MPE \\
\hline SOD & $11.72 \pm 0.86^{\mathrm{a}}$ & $11.80 \pm 0.71^{\mathrm{a}}$ & $7.30 \pm 0.57^{\mathrm{b}}$ & $9.54 \pm 0.82^{\mathrm{c}}$ \\
CAT & $52.08 \pm 3.19^{\mathrm{a}}$ & $51.32 \pm 3.20^{\mathrm{a}}$ & $32.40 \pm 2.33^{\mathrm{b}}$ & $37.55 \pm 2.90^{\mathrm{c}}$ \\
GPx & $5.30 \pm 0.36^{\mathrm{a}}$ & $5.60 \pm 0.52^{\mathrm{a}}$ & $2.55 \pm 0.31^{\mathrm{b}}$ & $4.60 \pm 0.34^{\mathrm{c}}$ \\
GST & $6.12 \pm 0.38^{\mathrm{a}}$ & $6.20 \pm 0.27^{\mathrm{a}}$ & $2.87 \pm 0.33^{\mathrm{b}}$ & $3.62 \pm 0.22^{\mathrm{c}}$ \\
\hline
\end{tabular}

Values are mean \pm SD for 6 rats in each group.

SOD - one unit of activity was taken as the enzyme reaction, which gave $50 \%$ inhibition of NBT reduction in $1 \mathrm{~min} / \mathrm{mg}$ protein.

$\mathrm{CAT}-\mathrm{mmol}$ of $\mathrm{H}_{2} \mathrm{O}_{2}$ utilized/min/mg protein.

$\mathrm{GPx}-\mathrm{mg}$ of $\mathrm{GSH}$ consumed $/ \mathrm{min} / \mathrm{mg}$ protein.

GST - mmol of CDNB-GSH conjugate formed/min/mg protein.

${ }^{a, b \& c}$ Values not sharing a common superscript letter ( $a, b$ \& $)$ differ significantly at $\mathrm{p}<0.05$ (DMRT) 


\subsection{Non-enzymatic antioxidants status}

Table 4 shows changes in the levels of renal non enzymatic antioxidant in control and experimental rats. A significant $(\mathrm{p}<0.05)$ decreased levels of non enzymatic antioxidants (GSH, TSH, Vit.C and Vit.E) were observed in Cd treated rats. When administration of MPE $(100 \mathrm{mg} / \mathrm{kg} /$ day $)$ to Cd treated rats shows a significant $(\mathrm{p}<0.05)$ increase in the levels of non enzymatic antioxidants when compared with Cd treated kidney of rats.

Table 4: Effect of MPE and cadmium on the activities of Non-enzymatic antioxidants in kidney of control and experimental rats.

\begin{tabular}{|c|c|c|c|c|}
\hline Groups & Control & MPE & $\mathrm{Cd}$ & $\mathrm{Cd}+\mathrm{MPE}$ \\
\hline $\mathrm{GSH}$ & $2.57 \pm 0.20^{\mathrm{a}}$ & $2.60 \pm 0.25^{\mathrm{a}}$ & $1.35 \pm 0.98^{b}$ & $2.25 \pm 0.30^{\mathrm{c}}$ \\
\hline $\mathrm{TSH}$ & $10.29 \pm 0.75^{\mathrm{a}}$ & $10.50 \pm 0.75^{\mathrm{a}}$ & $7.58 \pm 0.43^{b}$ & $8.09 \pm 0.50^{c}$ \\
\hline Vit. C & $0.95 \pm 0.02^{\mathrm{a}}$ & $0.96 \pm 0.05^{\mathrm{a}}$ & $0.54 \pm 0.05^{\mathrm{b}}$ & $0.70 \pm 0.02^{c}$ \\
\hline Vit. E & $0.64 \pm 0.04^{\mathrm{a}}$ & $0.68 \pm 0.04^{b}$ & $0.25 \pm 0.03^{c}$ & $0.39 \pm 0.07^{\mathrm{c}}$ \\
\hline
\end{tabular}

Values are mean \pm SD for 6 rats in each group.

a, b \&c Values not sharing a common superscript letter (a, b \&c) differ significantly at $\mathrm{p}<0.05$ (DMRT).

\subsection{Membrane bound ATPases}

The activities of $\mathrm{Na}^{+}, \mathrm{K}^{+}, \mathrm{Ca}^{2+}$ and $\mathrm{Mg}^{2+}$ ATPase significantly $(\mathrm{p}<0.05)$ decreased in the kidney tissue of Cd treated rats as compared to normal controls (Table 5). Administration of MPE significantly $(\mathrm{p}<0.05)$ prevented the decrease in the activities of all ATPases in Cd intoxicated rats. MPE alone treated group did not show any alteration in the activities of these ATPases in the kidney.

Table 5: Changes in the activities of renal membrane bound ATPases of control and experimental rats.

\begin{tabular}{lllll}
\hline Groups & Control & MPE & Cd & Cd+MPE \\
\hline Total ATPase & $1.56 \pm 0.25^{\mathrm{a}}$ & $1.57 \pm 0.27^{\mathrm{a}}$ & $0.92 \pm 0.10^{\mathrm{b}}$ & $1.09 \pm 0.16^{\mathrm{c}}$ \\
$\mathrm{Na}^{+} / \mathrm{K}^{+}$ATPase & $0.63 \pm 0.05^{\mathrm{a}}$ & $0.65 \pm 0.06^{\mathrm{a}}$ & $0.32 \pm 0.04^{\mathrm{b}}$ & $0.50 \pm 0.06^{\mathrm{c}}$ \\
$\mathrm{Ca}^{2+}$ ATPase & $0.55 \pm 0.07^{\mathrm{a}}$ & $0.56 \pm 0.05^{\mathrm{a}}$ & $0.40 \pm 0.04^{\mathrm{b}}$ & $0.54 \pm 0.06^{\mathrm{c}}$ \\
$\mathrm{Mg}^{2+}$ ATPase & $0.68 \pm 0.06^{\mathrm{a}}$ & $0.69 \pm 0.06^{\mathrm{a}}$ & $0.52 \pm 0.05^{\mathrm{b}}$ & $0.65 \pm 0.06^{\mathrm{c}}$ \\
\hline
\end{tabular}

Values are given as mean \pm SD from six rats in each group. Values not sharing a common superscript letter (a, b \& c) differ significantly at $\mathrm{p}<0.05$ (DMRT). ATPases- $\mu$ g Pi liberated $/ \mathrm{min} / \mathrm{mg}$ protein.

\subsection{Renal nitric oxide (NO) and TNF- $\alpha$}

The levels of TNF- $\alpha$ and NO were significantly ( $>00.05)$ increased in the kidney tissues of Cd treated rats when compared with the control groups. Administration of MPE along with Cd significantly ( $\mathrm{p}>0.05)$ decreased the levels of TNF- $\alpha$ and NO (Fig.3) when compared with Cd treated rats. In MPE alone treated rats, the levels of renal TNF- $\alpha$ and NO were not much altered and were comparable to those of the control rats.

\subsection{Histological examination of kidney tissue}

Figure 4 exhibits histopathological microscopic images of intact rat kidney observed in control group (Fig. 4A). The histoarchitectural pattern of kidney was almost normal in MPE alone administered rats (Fig. 4B). kidney cells of animals exposed to $\mathrm{Cd}$ for four weeks induces several pathological changes such as severe tubular necrosis, inflammatory cell infiltration, tubular degeneration, hemorrhage, swelling of tubules and vacuolization (Fig. 4C). Administration of MPE to the Cd treated rat showed effectively attenuated the histopathological abnormalities in kidney of rats (Fig. 4D). 
$\mathbf{A}$

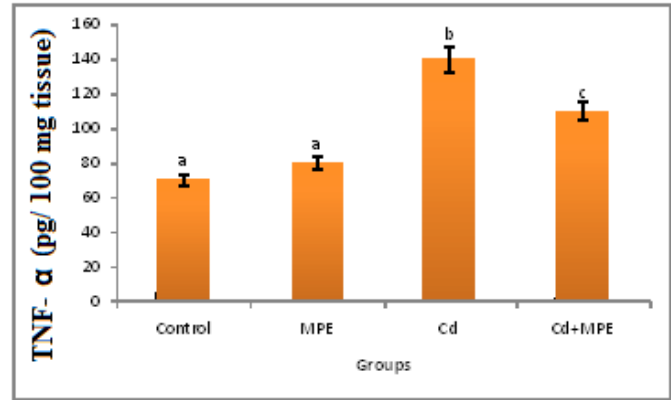

B

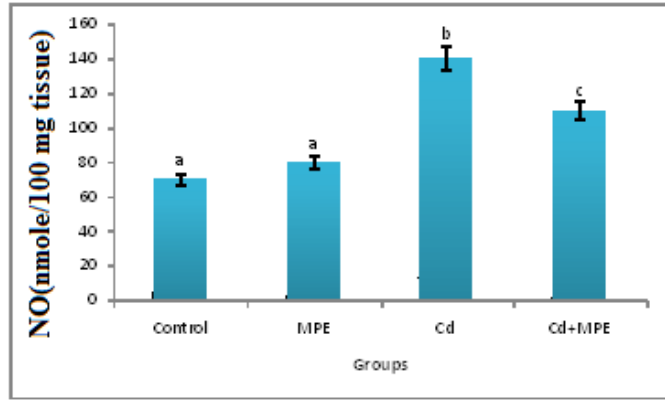

Fig. 3: Effects of MPE treatment on renal (A) tumour necrosis factor- $\alpha$ (TNF- $\alpha$ ); (B) nitric oxide (NO) levels in rats with nephrotoxicity induced by Cd. Values are mean \pm S.D. for six rats in each group. Bars not sharing a common superscript letter (a-c) differ significantly at $p<0.05$ (DMRT).
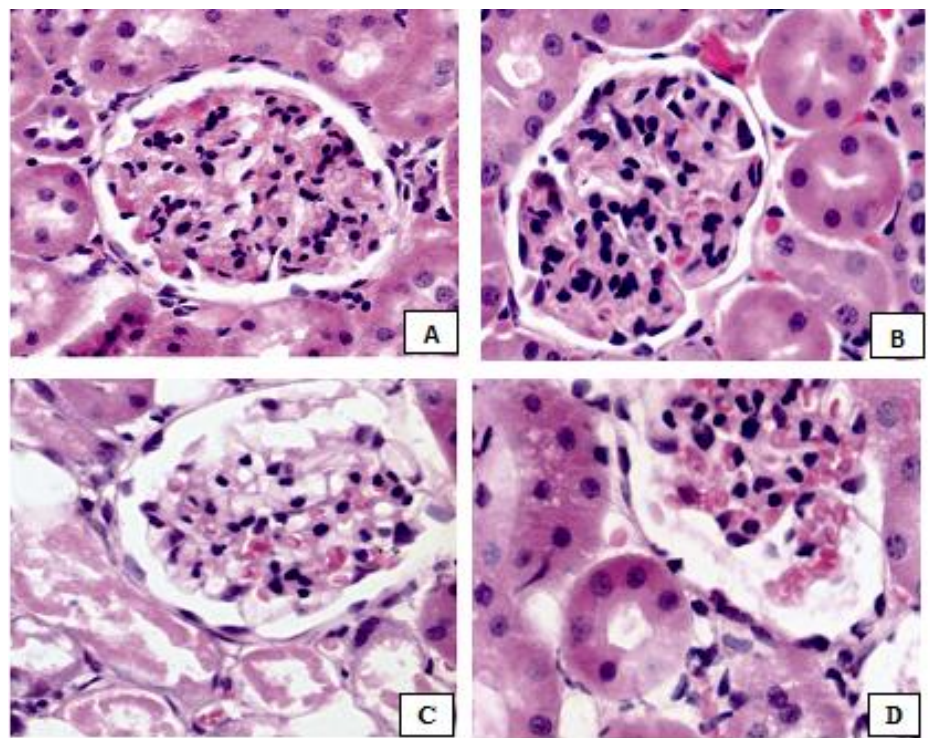

Fig. 4. Photomicrographs of rat kidney (H \& E) from: (A, 200X) control group showing normal renal architecture; (B, 200X) MPE alone treated group showing normal histological picture of the renal tissue. (C, 200X) Cd treated group showing widespread inflammation, shirnkened glomerulus, necrosis with dilatation of tubules, vacuolar degeneration, epithelial desquamation and intraluminal cast formation in the proximal tubules; (D, 200X) Cd plus MPE treated group displaying marked improvement in the renal histological architecture which is comparable to that of the control group.

\section{Discussion}

Experimental induction of oxidative stress mediated nephrotoxicity by $\mathrm{Cd}$ in rats is a well established model to study the protective nature of different nephroprotective phytoextracts [23]. Cadmium is a serious environmental and occupational toxicant and exerts multiple organ dysfunctions and chronic exposure to Cd mainly affects the kidneys [46, 47]. In renal cells the $\mathrm{Cd}-\mathrm{MT}$ complex is dissolved, free $\mathrm{Cd}$ is released and absorbed by proximal tubules. If kidney's MT defense and detoxification systems are overwhelmed, free Cd can damage the renal tubules [48]. Kidney injury due 
to $\mathrm{Cd}$ intoxication could be assessed by measuring the serum and urinary markers of kidney damage which are the biochemical hallmarks of renal damage. In the present investigation increased urea, uric acid and serum creatinine, decreased levels of creatinine clearance shows the diagnosis of renal damage in the cadmium treated rats. Urea is the major nitrogen-containing metabolic product of protein metabolism. Uric acid is the major product of purine nucleotides, adenosine and guanosine. It is well established that $\mathrm{Cd}$ inhibits the integration of amino acid in to protein, causing an increase in urea level. Serum levels of urea and creatinine were used as indicators of renal function. Increased levels of urea in blood is known to indicate that the increased protein catabolism in animals and the conversion of ammonia to urea as a result of increased synthesis of arginase enzyme involved in urea production [49]. When administration of MPE protects the kidney function from cadmium induced free radicals in rats and restored the levels of those serum markers in the kidney. It is due to the presence of antioxidant such as euginol, rosmarinic acid, caffeic acid and $\alpha$-tocopheral in the extract of mentha piperita [15-17].

$\mathrm{Cd}$ induced kidney damage is associated with increased lipid peroxidation [50]. Cell membranes are phospholipids bilayers with extrinsic proteins and are the direct target of lipid peroxidation which leads to indirect production of lipid hydroperoxides and protein carbonyl content in the Cd treated rat kidneys. Early study reported [51] that the cadmium induced kidney damage in rats was increased with the lipid peroxidation, lipid hydroperoxides and protein carbonyl content. Our findings also line with this report that the $\mathrm{Cd}$ treated rats shows the elevated levels of oxidative stress markers in the kidney. Results suggest that MPE treatment prior to $\mathrm{Cd}$ intoxication could prevent the $\mathrm{Cd}$ induced alterations of antioxidant related parameters in experimental animals.

Superoxide dismutase (SOD), catalase (CAT) and glutathione peroxidase (GPx) constitute mutually a supportive team of defense against reactive oxygen species (ROS). SOD is a metallo protein that catalyses the dismutation of superoxide radicals [52]. Catalase is a heme protein which catalyses the reduction of $\mathrm{H}_{2} \mathrm{O}_{2}$ to water and oxygen and thus protects the cell from oxidative damage by $\mathrm{H}_{2} \mathrm{O}_{2}$ and $\mathrm{OH}^{-}$[53]. Glutathione peroxidase is a Selene enzyme, which plays a major role in the reduction of $\mathrm{H}_{2} \mathrm{O}_{2}$ and hydro peroxide to non-toxic products [54]. Previous study [55] reported that the levels of enzymatic antioxidant in arsenic treated rat kidney were significantly decreased due to the production of ROS in the kidney. Miltonprabu et al [56] who reported that the depletion of enzymatic antioxidant levels in Cd treated rats shows increased oxidative stress due to the unpaired electrons in their atoms. Our result also corroborate with the previous findings that the levels of enzymatic antioxidant in the $\mathrm{Cd}$ treated rats significantly decreased. Administration with MPE to the Cd treated rats shows the significant elevated levels of enzymatic antioxidants in the kidney. This is due to the presence of natural antioxidant.

GSH, Vit.C and Vit.E are the secondary line of protectors from ROS formation in cells. It is tripeptide (L-a glutamyl cysteinyl glycine), an antioxidant and a powerful nucleophile, critical for cellular protection such as detoxification of ROS, conjugation with xenobiotics, excretion of toxic molecules and control the inflammatory cytokines etc. Depletion of GSH in tissues leads to the impairment of cellular defense against ROS and may result in peroxidative tissue injury [57]. In the present study the Cd treated rats showed a significant depletion of non enzymatic antioxidants in kidney such as, reduced glutathione (GSH), Total sulfhydryl group (TSH), Vit. C and Vit. E. Administration of MPE to Cd treated rats shows significant increased in the levels of non enzymatic antioxidant near to normal control. This may be due to free radicals abrogation ability of antioxidant such as euginol, rosmarinic acid, caffeic acid and $\alpha$-tocopheral which is present in the MPE.

The determination of membrane associated enzyme activities like adenosine triphosphatases (ATPases) indicates the changes in membranes under pathological conditions [58]. The changes in ionic concentrations can bring about diverse types of cell injury, which ultimately lead to cell death [59]. Earlier studies [60] have reported the decreased levels of membrane bound ATPases in the metal induced oxidative damage on kidney of rats. Our results also strongly agree with the previous reports that the administration of $\mathrm{Cd}$ to the rats exhibited a remarkable diminution in the activities of membrane bound ATPases in the kidney. Administration of MPE to the Cd treated rats exhibited a significant recovery in the activities of membrane bound ATPases in the kidney. This is depending upon the antioxidant properties of MPE, which neutralize the oxidative reactions. MPE administration significantly reduced the lipid peroxidation via its ROS scavenging ability and improved the levels of endogenous antioxidants through which, it exerts membrane protection. Tumor necrosis factor $(\mathrm{TNF}-\alpha)$ is a cytokine involved in systemic inflammation and is a member of a group of cytokines that stimulate the acute phase reaction. It is produced chiefly by activated macrophages, although it can be produced by many other cell types as CD4+ T-lymphocytes, NK cells and neurons [61, 62]. Up regulation of TNF- $\alpha$ level has been implicated in a variety of human diseases including the inflammatory response, which in turn may cause many of the clinical problems associated with autoimmune disorders such as rheumatoid arthritis, ankylosing spondylitis, inflammatory bowel disease, psoriasis, hidradenitis suppurativa and refractory asthma [63]. Nitric oxide (NO) has a major role as a messenger molecule in most human organ systems [64]. However, higher concentrations of NO can be toxic and damaging cellular constituents such as DNA and inducing hypotension in those with sepsis [65]. Both TNF- $\alpha$ and NO is the indicators of kidney inflammation and poses increased oxidative threat to the exposed subjects. In the present investigation Cd intoxicated rats showed a marked increase in the levels of TNF- $\alpha$ and NO in the renal tissue clearly signifies the inflammation. Administration of MPE to the Cd treated rats exhibited a significant reduction in the levels of renal TNF- $\alpha$ and NO which shows the anti-inflammatory ability of MPE. 
The renoprotective nature of MPE is further evidenced by the histological findings. The histopathological observation in $\mathrm{Cd}$ treated rats showed the tubular necrosis, inflammatory cell infiltration, tubular degeneration, hemorrhage, swelling of tubules and vacuolization (Fig.4C). This could be due to the increased formation of lipid peroxidation end products and protein carbonylation in the renal tissue which leads to damage in membrane integrity and other pathological changes in Cd intoxicated rats. Administration of MPE significantly diminished the histological alterations provoked by $\mathrm{Cd}$ is quite appreciable. It can be attributed to the antiradical, antioxidant, anti-inflammatory and metal chelating efficacy of MPE which significantly reduced the oxidative stress, leading to the reduction of histopathological alterations and restoration of normal physiological state of an organism (Fig.4D). Further, the membrane stabilizing properties of antioxidants present in MPE might be helpful to improve the histopathological alterations caused by Cd in the renal tissue of rats.

\section{Conclusion}

In conclusion, the outcome of the present study indicates that MPE significantly protected against Cd-induced oxidative stress mediated nephrotoxicity in rats. The antioxidant, anti-inflammatory and membrane stabilizing activities can be considered as the key factors responsible for the nephroprotective effect of MPE. Therefore, MPE represents a prospective therapeutic choice to avert the renal oxidative injury inflicted by $\mathrm{Cd}$ in exposed subjects.

\section{Conflicts of interest statement}

The author declares that there are no conflicts of interest.

\section{Acknowledgements}

Authors extend their thanks to the Professor and Head, Department of Zoology and UGC-SAP for their generous support in this study.

\section{References}

[1] Urani C, Melchioretto P, Canevali C, Morazzoni F, Gribaldo L. Metallothionein and hsp70 expression in HepG2 cells after prolonged cadmium exposure. Toxicol. In Vitro 2007; 21: 314-319.

[2] Amoruso MA, Witz, G, Goldstein, BD. Enhancement of rat and human phagocyte superoxide anion radical production by cadmium in vitro. Toxicol. Lett. 1982; 10:133-138.

[3] Zhong Z, Troll W, Koenig KL, Frenkel K. Carcinogenic sulfide salts of nickel and cadmium induce $\mathrm{H}_{2} \mathrm{O}_{2}$ formation by human polymorphonuclear leukocytes. Cancer Res.1990; 20:7564-7570.

[4] Ochi T, Otsuka F, Takahashi K, Oshawa M. Glutathione and metallothioneins as cellular defense against cadmium toxicity in culture Chinese hamster cells. Chem. Biol. Interactions 1988; 65:1-14.

[5] Sugiyama M. Role of cellular antioxidants in metal-induced damage. Cell. Biol. Toxicol. 1994; 10:1-22.

[6] Bernard A. Cadmium and its adverse effects on human health. Indian J.Med Res. 2008; 128: 557-564.

[7] Valko M, Morris H, Cronin MT. Metals, toxicity and oxidative stress. Curr. Med. Chem. 2005; 12, 1161-1208.

[8] Rikans LE, Yamano T. Mechanisms of cadmium mediated acute hepatotoxicity. J Biochem Mol Toxicol. 2000; 14:110-7.

[9] Wang Y, Fang J, Leonard SS, Rao KMK. Cadmium inhibits electron transfer chain and induced reactive oxygen species. Free Radic Biol Med. 2004; 36:1434-43.

[10] Morales AI, Vicente-Sanchez C, Egido J, Arevalo MA, Lopeznovoa JM. Protective effect of quercetin on experimental chronic cadmium nephrotoxicity in rats is based on its antioxidant properties. Food Chem Toxicol. 2006; 44: 2092-100.

[11] Herak-Kramberger CM, SabolicI. The integrity of renal cortical brush-border and basolateral membrane vesiclesis damaged invitro by nephrotoxic heavymetals. Toxicology. 2001; 156:139-47.

[12] Shaikh ZA, Vu TT, Zaman K. Oxidative stress as a mechanism of chronic cadmium induced hepatotoxicity and renal toxicity and protection by antioxidants. Toxicol Appl Pharmacol. 1999; 154:256-63.

[13] Vallee BL, Ulmer DD. Biochemical effects of mercury, cadmium and lead. Annu Rev Biochem. 1972; 41:91-128.

[14] Uivarosi V, Barbuceanu SF, Aldea V, Arama CC, Badea M, Olar R, Marinescu D. Synthesis, spectral and thermal studies of new rutin vanadyl complexes. Molecules 2010; 15:1578-1589

[15] Rastogi RP, Mehrotra BN. Compendium of Indian Medicinal Plants, Vol. 3 (1980-81). CDRI and PID, New Delhi, India, $1991 ; 420$.

[16] Krishnaswamy K, Raghuramulu N. Bioactive phytochemicals with emphasis on dietary practices. Indian J Med Res. 1998; $108: 167-81$.

[17] Al Seriti MR, Abu Amer RM, Sen P. Pharmacology of rosemary (Rosemarinus officinalis Linn.) and its therapeutic potentials. Indian J Exp Biol. 1999; 37:124-30.

[18] Simões CMO, Spitzer V. Óleos voláteis. In - Farmacognosia da planta ao medicamento, Universidade Federal do Rio Grande do Sul, Porto. 2000 
[19] Gulluce M, Sahin F, Sokmen M, Ozer H, Daferara D, Sokmen A, Polissiou M, Adiguzel A, Ozkan H . Antimicrobial and antioxidant properties of the essential oils and methanol extract from Mentha longifolia L. ssp. longifolia. Food Chem. 2007 ; 104 (4): $1449-1456$.

[20] Rasooli I. Dental Biofilm prevention by Mentha spicata and Eucalyptus camaldulensis essential oils. Int. J. Infect. Dis. 2008 ; $12(1)$ : 167.

[21] Edris A. Pharmaceutical and therapeutic potentials of essentials oils and their individual volatile constituents: A Review.x Phytother Res. 2006; 20: 1-16.

[22] Bassole IH, Lamien-Meda A, Bayala B, Tirogo S, Franz C, Novak J, et al. Composition and antimicrobial activities of Lippia multiflora , Mentha piperita L. and Ocimum basilicum L. essential oils and their major monoterpene alcohols alone and in combination. Molecules. 2010; 15: 7825-39.

[23] Renugadevi J. MiltonPrabu S. Quercetin protects against oxidative stress- related renal dysfunction by cadmium in rats. Experimental and Toxicologic Pathology 2010; 62: 471-481.

[24] Sirivasan V, Gillespie BE, Lewis MJ, Nguyen LT, Headrick SI, Schukken YH, Okidney SP. Phenotypic and genotypic antimicrobial resistance patterns of Escherichia coli isolated from dairy cows with mastitis. Veterinary Microbiology. 2007; 124: $319-328$.

[25] Piccolella S, Fiorentino A, Pacifico S, Dwbrosca B, Uzzo P, Monaco P. Antioxidant properties of sour cherries (Prunus cerasus L.): role of colorless phytochemicals from the methanolic extract of ripe fruits. Journal of Agricultural and Food Chemistry. 2008; 56: 1928-1935.

[26] Niehaus WG, Samuelsson B. Formation of malondialdehyde from phospholipid arachidonate during microsomal lipid peroxidation. European Journal of Biochemistry. 1968; 6: 126-130.

[27] Jiang ZY, Hunt JY, Wolff SP. Detection of lipid hydroperoxides using the Fox reagent. Analytical Biochemistry. 1992; 202 : $384-389$.

[28] Levine RL, Garland D, Okidney CN, Amic A, Climent I, Lenz AG, Ahn BW, Shaltiel S, Stadtman ER. Determination of carbonyl content in oxidatively modified proteins. Methods in Enzymology. 1999; 186: 464-478.

[29] Rao KS, Recknagel RO. Early onset of lipid peroxidation in rat kidney after carbon tetrachloride administration. Experimental and Molecular Pathology. 1968; 9: 271-278.

[30] Ellman GL. Tissue sulphydryl groups. Archives of Biochemistry and Biophysics 1959; 82: 70-77.

[31] Hissin PJ, Hilf RA. A fluorometric method for determination of oxidized and reduced glutathione in tissues. Analytical Biochemistry. 1976; $74,214-226$.

[32] Sedlak J, Lindsay RH. Estimation of total, protein-bound and non-protein sulphydryl groups in tissue with Ellman's reagent. Annals of Biochemistry. 1958; 24: 192-205.

[33] Omaye ST, Turbull TD, Sauberlich HC. Selected method for the determination of ascorbic acid in animal cells, tissues and fluids. In: McCormic DB, Wright DL. (Eds.), Methods in Enzymology. 1979; Academic Press, New York, USA, pp. 3-11.

[34] Desai ID. Vitamin E analysis method for animal tissues. Methods in Enzymology. 1984; 105: 138-143.

[35] Kakkar P, Das B, Viswanathan PN. A modified spectrophotometric assay of superoxide dismutase. Indian Journal of Biochemistry and Biology. 1984; 21: 130-132.

[36] Sinha AK. Colorimetric assay of catalase. Analytical Biochemistry. 1972.

[37] Rotruck JT, Pope AL, Ganther HE, Swanson AB, Hafeman DC, Hoekstra WG. Selenium: biochemical roles as a component of glutathione peroxidase. Science. 1973; 9: 588-590.

[38] Habig WH, Pabst MJ, Jakoby WB. Glutathione Stransferase the first step in mercapturic acid formation. Journal of Biological Chemistry. 1974; 249: 7130-7139.

[39] Hoffman D. The complete illustrated holistic herbal. Rockport, MA: Element Books Inc. 1996.

[40] Beutler E. Active transport of glutathione disulfide from erythrocytes. In: Larson A, Orrenius S, Holmgren A, Mannerwik B.E.D.S. (Eds.) Functions of Glutathione, Biochemical, Physiological, Toxicological and Clinical Aspects 1983; Raven Press, New York, p. 65.

[41] Bonting SL. Presence of enzyme system in mammalian tissues. In: Bilter EE (ed) Membrane and ion transport. Wiley Inter Science. 1970; London, pp 257-263

[42] Hjerten S, Pan H. Purification and characterization of two forms of low affinity Ca2+-ATPase from erythrocyte membrane. Biochim Biophys Acta. 1983; 728:281-288

[43] Ohnishi T, Suzuki T, Suzuki Y, Ozawa K. A comparative study of plasma membrane Mg2+-ATPase activities in normal, regenerating and malignant cells. Biochim Biophys Acta .1982; 684:67-74.

[44] Lowry, OH, Rosebrough NJ, Farr AL, Randall RJ. Protein measurement with Folin-phenol reagent. Journal of Biological Chemistry. 1951; 193: $265-275$.

[45] Green LC, Wagner DA, Glogowski J, Skipper PL, Wishnok JS, Tannenbaum SR. Analysis of nitrate, nitrite, and [15N] nitrate in biological fluids. Anal Biochem 1982; 126:131-138.

[46] Satarug S, Garrett S.H, Sens MA, Sens DA. Cadmium, environmental exposure, and health outcomes. Environ. Health Perspect. 2010; 118: $182-190$.

[47] Jin T, Nordberg M, Frech W, Dumont X, Bernard A, Ye TT, et al. Cadmium biomonitoring and renal dysfunction among a population environmentally exposed to cadmium from smelting in China. Biometals. 2002; 15:397-410.

[48] Patrick L. Toxic metals and antioxidants: part II. The role of antioxidants in arsenic and cadmium toxicity. Altern Med Rev. 2003; 8:106-28.

[49] Milton Prabu S, Shagirtha K, Renugadevi J. Quercetin in combination with vitamins (C and E) improves oxidative stress and renal injury in cadmium intoxicated rats. European Review for Medical and Pharmacological Sciences. 2010; 14: $903-914$.

[50] Renugadevi J, Prabu SM. Naringenin protects against cadmium-induced oxidative renal dysfunction in rats. Toxicology. 2009; 256(1-2):12834.

[51] Jin T, Nordberg M, Frech W, Dumont X, Bernard A, Ye Tt, Kong Q, Wang Z, Li P, Lundstrom Ng, Li Y, Nordberg GF. Cadmium biomonitoring and renal dysfunction among a population environmentally exposed to cadmium from smelting in China. Biometals. 2002; 15 : 397-410.

[52] McCord JM, Keele BB, Fridovich I. An enzyme based theory of obligate anaerobiosis. The physiological functions of superoxide dismutase. Proc Natl Acad Sci USA. 1976; 68:1024-7.

[53] Chance B, Greenstein DS, Roughton RJW. The mechanism of catalase action 1-steady state analysis. Arch Biochem Biophys. 1952; 37:30139.

[54] Bruce A, Freeman D, James C. Biology of disease-free radicals and tissue injury. Lab Invest. 1982; 47:412-26.

[55] Milton Prabu S, Muthumani, M. Silibinin ameliorates arsenic induced nephrotoxicity by abrogation of oxidative stress, inflammation and apoptosis in rats. Mol Biol Rep. 2012; DOI 10.1007/s11033-012-2029-6

[56] Milton Prabu S, Muthumani M, Shagirtha K. Protective effect of Piper betle leaf extract against cadmium-induced oxidative stress and hepatic dysfunction in rats. Saudi Journal of Biological Sciences. 2012; 19: 229-239.

[57] Hossain SK, Bhattacharya S. Hesperetin protects against oxidative stress related hepatic dysfunction by cadmium in rats. Environ Toxicol Pharmacol 2006; 22: 298-308. 
[58] Kempaiah RK, Srinivasan K. Protective effect of curcumin, capsaicin and garlic on erythrocyte integrity in high fat fed rats. J. Nutr. Biochem. 2006; 17: 471-478.

[59] Kane AB. Mechanisms of cell and tissue injury. In: Sirica AE, (Ed). Cellular and Molecular Pathogenesis 1996; Lippincott-Raven Publishers, Philadelphia, USA. pp. 1-22.

[60] Thangapandiyan S, Miltonprabu S. Epigallocatechin gallate effectively ameliorates fluoride induced oxidative stress, DNA damage in the liver of rats. Canadian Journal of Physiology and Pharmacology, 2013, 91(7): 528-537.

[61] Swardfager W, Lanctôt K, Rothenburg L, Wong A, Cappell J, Herrmann N. "A meta-analysis of cytokines in Alzheimer's disease". Biol Psychiatry 2010; 68 (10): 930-941.

[62] Locksley RM, Killeen N, Lenardo MJ. The TNF and TNF receptor superfamilies: Integrating Mammalian biology. $2001 ; 104$ (4): $487-501$.

[63] Dowlati Y, Herrmann N, Swardfager W, Liu H, Sham L, Reim EK, Lanctôt KL. "A meta-analysis of cytokines in major depression. Biol Psychiatry. 2010; 67 (5) 446-457.

[64] Kone BC. Nitric oxide synthesis in the kidney: isoforms, biosynthesis, and functions in health. Semin Nephrol. 2004; 24:299.

[65] Marsden PA, Brenner BM. Nitric oxide and endothelins: novel autocrine/paracrine regulators of the circulation. Semin Nephrol. 1991; 11:169. 